\title{
The History of Evolution of Life on Earth Told by Paleoparasitology
}

\author{
Paula Cascardo, Elisa Pucu and Daniela Leles* \\ Departamento de Microbiologia e Parasitologia, Universidade Federal Fluminense, Brazil
}

Submission: February 26, 2017; Published: April 11, 2017

*Corresponding author: Daniela Leles, Departamento de Microbiologia e Parasitologia, Universidade Federal Fluminense, R. Prof. Hernani Melo, 101 - São Domingos, Niterói - RJ, 24210-130, Brazil, Email: dleles@id.uff.br

\begin{abstract}
Through the study of parasites and other microorganisms in ancient material Paleoparasitology can presuppose on the way of life of our ancestors, established relations with and between animals and the environment, and their reflexes until the contemporary period dealing with several areas of knowledge. Therefore, it has been possible to recover intestinal parasites from coprolites of Cinodontes and Dicionodontes dating to 240mya, a group with important evolutionary aspects for the origin of mammals. The finding of primitive forms of Plasmodium spp., Trypanosoma spp., and Leishmania spp. in amber dating back thousands of years has shed light on discussions about the origin and evolution of parasite species that affect humans today. The study of lice DNA helped to discover when clothing emerged in mankind, and that was an important point for the conquest of the icy continents. The discovery of "geohemints" in coprolites of the Americas pre-Columbian period reaffirmed that the first Amerindians also arrived by the sea, and not exclusively by the Bering Strait. It showed the influence of diseases on the fall of emperors and wars such as the possible death of "Pharaoh Tutankhamun" from malaria, battles of the "Great Crusades" may have been lost due to chronic diarrhea caused by intestinal protozoa, or death of Napoleon soldiers by the trench fever. Thus Paleoparasitology helps to tell the story of life on earth using parasites as a clue.
\end{abstract}

Keywords: Paleoparasitology; Parasites; Extinct animals; Human history; Ancient DNA; Coprolite; Evolution

\section{Introduction}

Our ancestor's life, their relationships among animals and environment, and their evidences until the contemporary period, are only part of the potential that the Paleoparasitology line of research can unveil. This science studies parasites and other microorganisms such as bacteria, virus and fungi in ancient materials. Through it we are able to assume cultural habits, the interaction between the environment and other animals, the contact with other groups, human and animal migrations routes, landing modifications, and the development, spread and circulation of pathogens, which can influence what we observe in the planet today. Paleoparasitology can therefore contribute and dialogue with several different areas of expertise, such as archaeology, paleontology, anthropology, history, biogeography, microbiology and parasitology, among others. We currently work with evidence that are either indirect, such as historical documentation, iconography, and even bone lesions that leave clues of the parasite etiology; or direct evidence in which there is a proof of existence by microscopy, immune diagnostics or molecular biology of the parasites in a given sample, such as coprolites, latrines, amber, mummified tissues, bones, teeth, clothes, hair, funerary urns, among others. There were several discoveries done by this science, especially due to the innovations in the diagnostic methodology, related to the comparison with modern material.

In 1993, the first movie of the series "Jurassic Park" was released. It was directed by Steven Spielberg and inspired by the book written by Michael Crichton. In the movie, dinosaurs that live in the park were created by genetic engineering through the recovery of aDNA (ancient DNA) from hematophagous insects preserved in amber. In the scientific point of view in the present time, it is known that it is not possible to recover DNA fragments of dinosaurs, due to the fact that they lived millions of years ago and the recovery of ancient DNA is only possible until 1.5 millions of years. However even this date is contested due to the difficulty to recover DNA. Even with all the obstacles, Paleoparasitology has been making fantastic discoveries when studying extinct animals, even without the aid of molecular biology.

\section{Discussion}

In a paleontological site in Rio Grande do Sul, Brazil, species of intestinal parasites were discovered in coprolites of 240 million years from Cynodonts and Dicynodonts, a group with an 
evolutionary aspect important for the appearance of mammals $[1,2]$.

Studies with amber have generated important discussions in the origin of certain diseases, despite the impossibilities of aDNA recover on account of its antiquity. Researchers have found three hematophagous insects in the same amber piece, one of them is an insect of the genus Culex in which they found, primitive forms of Plasmodium spp., that causes malaria in human and non-human primates in the old and new world [3], and in a fecal drop of another insect, triatomine, primitive forms of Trypanosoma spp. Additionally, in this same piece researchers found mammal hair possibly from bats. This shows a probable 45 million year host-parasite interaction between bats and tripanosomas helping understand about the infection that occurs in humans by these parasites [4]. In another amber piece dated from $\sim 100-105$ millions of years flagellates were identified in environmental debris and also on the interior of a sand fly larvae prisoned inside the resin. Thus, it is discussed the origin of this parasite and how the cycle vertebrate-vector started, as today humans are also included in the leishmania transmission by mainly sand flies that ingest these flagellates [5].

The last mass extinction occurred during the Quaternary between 50.000 to 3.000 years ago, with the disappearance of two thirds of mammal genera and half of the species that weighted more than $44 \mathrm{~kg}$. The hypotheses brought up by scientists are human competition and predation [6], and drastic climate change that may have been the main cause of this mass extinction [7]. The extinct mammals of that period are, for instance, the mastodon, saber-tooth tiger, mammoths and the famous giant ground sloths that occurred in the late Pleistocene. Even though most studies that search parasites in extinct mammals are performed by the use of optical microscopy, such as the ones already published with coprolites of the extinct ground sloth $[8,9]$, the recovery of ancient DNA is a reality mainly for animals that lived until the end of the Quaternary, during the "Ice Age", condition that provide a good preservation of their organic remains. A molecular study done with coprolites of an extinct six-thousand-year old bird from New Zealand, Moa, identified DNA of Apicomplexa, Nematoda and Trematoda. While by optical microscopy only nematode eggs were identified [10], this study shows how important it is to combine different techniques.

Therefore, the studies of these materials give us plenty of information, such as: which parasites were present at that time; which were extinct with their hosts; which adapted and switched to new hosts; or even hybridized into a new species that could have then infected and parasitized humans or vice versa; or were extinct by the influence of humans. If we approximate the time scale we can find studies of animals that are extinct but occurred in the same period as the humans such as the caprines of Mallorca, Myotragus balearicus Bate 1909. In a paleoparasitological study with coprolite samples of these animals', cysts of Entamoeba sp. were found by microscopy.
These coprolites were also positive for Cryptosporidium spp. by immunodiagnostic. It is believed that the extinction of this caprine species occurred by the domestic species introduction that led to the spread of new pathogens to this isolated and nonimmune species [11].

A recent study of extinct rodents of the last century demonstrated with the aid of molecular biology, extinction due to an invasive exotic species [12]. Two species native to Christmas Island, in the East of the Indic Ocean would have gone extinct due to an infection by a trypanosomatid introduced by Rattus rattus, an exotic species in the island, according to the parasitologist Durham [13] R. rattus would have carried infected fleas infesting consequently the native species of the island: Rattus macleari e Rattus natwitatis. These native species are then susceptible hosts with high sensibility that caused their extinction in only nine years, between 1899 and 1908. In this study, Wyatt et al. [12] found Trypanosoma lewisi DNA in specimens of $R$. macleari and Rattus natwitatis that were collected after the introduction of black rats in the island and did not in R. nativitatis specimen collected before. This study supported H.E. Durham's hypothesis, even though only few specimens were analyzed.

Thus, the study of ancient diseases can be an aid in understanding more about life conditions at the time. Also, it can tell us the risks of introducing new species in established ecosystems. Parasites also occurred on humans when they first appeared, either by the interaction with other animals and their environment or host switching. Finding these parasites helps us discover: population density due to the spread of some species of parasites and microorganisms; where the host went by; which parasites passed from animals to humans; what kind of food they ingested, if it was raw or cooked; and also the hygiene habits of different populations $[14,15]$.

One of the studies with lice DNA has helped find out when clothes started to be worn by humans, which was an important factor for their spread in cold continents. This study was possible when they separately dated the head louse (Pediculus humanus capitis) from the body louse (Pediculus humanus humanus). The body louse spends its entire life attached to the host clothes, only going to the host's skin for hematophagy. This louse species could only have occurred on humans after clothes started being worn [16].

A study by Dr. Araujo et al. [17] was able to corroborate and reaffirm that the first inhabitants of the American continent also arrived by the sea, and not exclusively by the Bering Strait. Scientists found geo-helminthes, parasites that spend part of their life cycle in the soil with suitable abiotic conditions, i.e. temperature, humidity and oxygen, to maintain their life cycle in their human hosts and be transmitted to the other potential hosts. Thereby, finding these human specific parasites in the coprolites of the first inhabitants of the American continent shows that they arrived already parasitized. Also, these parasites 
could not have survived if they passed through the Bering Strait with freezing temperatures.

Paleoparasitology also helps rewrite events that were part of the history of humankind. One of the biggest mysteries was King's Tutankhamun cause of death. Paleoparasitology, with the aid of molecular biology was able to recover DNA vestiges of Plasmodium falciparum. This species is more aggressive, and since the pharaoh's health was debilitated, he could have passed away of malaria [18]. Diseases could also have an impact on wars: historical documentation relates that soldiers and nobles part of the "Great Crusades" suffered from chronic diarrhea. The cause can be found with the study of the latrines that were used by the members of the "Great Crusades", where researchers detected intestinal protozoa antigens [19]. In the case of Napoleon Bonaparte's army, it was not only the cold that was a problem for the soldiers and had an impact on their health, but also a species of bacteria that causes trench fever, Bartonella quintana, transmitted by body lice. This species is more abundant in people with immune deficiency, and could have led to the soldiers' death since they showed no evidence of war injuries [20].

\section{Conclusion}

As we have seen thus far, Paleoparasitology is a science in expansion. Today there are several research groups in several parts of the world trying to evince the evolutionary history of life on earth and its implications on the modern days.

\section{Acknowledgment}

Financial Support: FAPERJ - Fundação de Amparo à Pesquisa do Estado do Rio de Janeiro.

\section{Conflict of Interest}

We declare that there is no economic interest or conflict of interest

\section{References}

1. da Silva P, Borba VH, Dutra JMF, Leles D, da-Rosa AAS, et al. (2014) A new ascarid species in cynodont coprolite dated of 240 million years. An Acad Bras Ciênc 86(1): 265-269.

2. Hugot JP, Gardner SL, Borba V, Araujo P, Leles D, et al. (2014) Discovery of a 240 million year old nematode parasite egg in a cynodont coprolite sheds light on the early origin of pinworms in vertebrates. Parasit Vectors 7(1): 486.

3. Poinar G (2005) Plasmodium dominicana n. sp. (Plasmodiidae: Haemospororida) from Tertiary Dominican amber. Syst Parasitol 61(1): 47-52.

4. Poinar G (2005) Triatoma dominicana sp. n. (Hemiptera: Reduviidae: Triatominae), and Trypanosoma antiquus sp. n. (Stercoraria: Trypanosomatidae), the first fossil evidence of a triatominetrypanosomatid vector association. Vector Borne Zoonotic Dis 5(1):
72-81.

5. Poinar G (2007) Early Cretaceous trypanosomatids associated with fossil sand fly larvae in Burmese amber. Mem Inst Oswaldo Cruz 102(5): 635-637.

6. Barnosky AD (2008) Megafauna Biomass Tradeoff as a Driver of Quaternary and Future Extinctions. In: Avise JC, Hubbell SP, Ayala FJ (Eds.), In the Light of Evolution. Volume II: Biodiversity and Extinction, The National Academies Press 500 Fifth Street., N.W. Washington, DC, USA, pp. $227-241 \&$ p. 432.

7. Lorenzen ED, Nogués-Bravo D, Orlando L, Weinstock J, Binladen J, et al. (2011) Species-specific responses of Late Quaternary megafauna to climate and humans. Nature 479(7373): 359-364.

8. Ringuelet RA (1957) Restos de probables huevos de nematodes en el estiercol del edentado extinguido Mylodon listai (Ameghino). Ameghiniana 1(1-2): 15-16.

9. Schmidt GC, Duszynski DW, Martini PS (1992) Parasites of the Extinct Shasta Ground Sloth Nothrotheriopsshastensis, in Rampart Cave, Arizona. J Parasitol 78: 811-816.

10. Wood JR, Wilmshurst JM, Rawlence NJ, Bonner KI, Worthy TH, et al. (2013) A Megafauna'sMicrofauna: Gastrointestinal Parasites of New Zealand's Extinct Moa (Aves: Dinornithiformes). PLoS One 8(2): e57315.

11. Borba Nunes VH, Alcover JA, Silva VL, Cruz PB, Machado-Silva JR, et al. (2017) Paleoparasitological analysis of the extinct Myotragus balearicus Bate 1909 (Artiodactyla, Caprinae) from Mallorca (Balearic Islands, Western Mediterranean). Parasitol Int 66(22): 7-11.

12. Wyatt KB, Campos PF, Gilbert MT, Kolokotronis SO, Hynes WH, et al. (2008) Historical Mammal Extinction on Christmas Island (Indian Ocean) Correlates with Introduced Infectious Disease. PLoS One 3(11): e3602.

13. Durham HE (1908) Notes on Nagana and on some Haematozoa observed during my travels. Parasitology 1(03): 227-235.

14. Ujvari SC (2008) A história da humanidade contada pelos vírus. Editora Contexto, São Paulo, Brasil, p. 202.

15. Ferreira LF, Reinhard KJ, Araújo A (2011) Fundamentos da Paleoparasitologia. Fundação Oswaldo Cruz, Manguinhos, Rio de Janeiro, Brasil, p. 484.

16. Toups MA, Kitchen A, Light JE, Reed DL (2011) Origin of clothing lice indicates early clothing use by anatomically modern humans in Africa. Mol Biol Evol 28(1): 29-32.

17. Araujo A, Reinhard KJ, Ferreira LF, Gardner SL (2008) Parasites as Probes for Prehistoric Human Migrations? Trends Parasitol 24(3): 112-115.

18. Hawass Z, Gad YZ, Ismail S, Khairat R, Fathalla D, et al. (2010) Ancestry and pathology in King Tutankhamun's family. JAMA 303(7): 638-647.

19. Mitchell PD, Stern E, Tepper Y (2008) Dysentery in the crusader kingdom of Jerusalem: an ELISA analysis of two medieval latrines in the City of Acre (Israel). Journal of Archaeological Science 35(7): 18491853.

20. Raoult D, Dutour O, Houhamdi L, Jankauskas R, Fournier PE, et al. (2006) Evidence for Louse-Transmitted Diseases in Soldiers of Napoleon's Grand Army in Vilnius. J Infect Dis 193(1): 112-120. 
This work is licensed under Creative Commons Attribution 4.0 Licens

DOI: 10.19080/GJAA.2017.01.555560
Your next submission with Juniper Publishers will reach you the below assets

- Quality Editorial service

- Swift Peer Review

- Reprints availability

- E-prints Service

- Manuscript Podcast for convenient understanding

- Global attainment for your research

- Manuscript accessibility in different formats ( Pdf, E-pub, Full Text, Audio)

- Unceasing customer service

Track the below URL for one-step submission https://juniperpublishers.com/online-submission.php 